Y, $\triangle \mathrm{K} 32.01$

ББК 66.04

DOI 10.22394/1682-2358-2021-3-88-94

A.A. Makovsky, Candidate of Sciences (Politics), Senior Researcher at the Management and $\mathrm{Ad}$ ministrative Law Department, Pskov State University

S.S. Dmitriev, Head of the Pskov Region Administration Apparatus

\section{"POLITICAL" AND "RELIGIOUS" LABELS IN SOCIAL MEDIA AS A TOOL FOR POLITICAL MOBILIZATION}

Ways and methods of digital mobilization of citizens through forming political labels for protest actions are considered. The most popular social media in the Russian Federation are analyzed in terms of forming political labels, as well as the tone of information and the mechanisms for mobilizing citizens. The authors come to the conclusion that most commonly in practice a political label is a trivial linguistic sign that establishes a negative, discriminatory connection between a signifier and a political phenomenon.

Key words and word-combinations: political labels, political mobilization, digital mobilization, propaganda, social media, social media, VKontakte, Telegram.
A.А. Маковский, кандидат политических наук, старший научныги сотрудник кафедрь управления и административного права Псковского государственного университета (email: aamakovsky@mail.ru)

C.C. Aмитриев, руководитель аппарата администрачии Псковской области (email: pskovdmitriev@yandex.ru)

\section{«ПОАИТИЧЕСКИЕ» И «РЕАИГИОЗНЫЕ» ЯРАЫКИ В СОЦИААЬНЫХ МЕАИА КАК ИНСТРУМЕНТ ЦИФРОВОЙ МОБИАИЗАЦИИ}

Аннотация. Рассматриваются способы и методы цифровой мобилизации граждан через формирование политических ярлыков на протестные действия. Анализируются наиболее популярные в России социальные медиа на предмет формирования политических ярлыков, а также тональность информации и представленных механизмов мобилизации граждан. Делается вывод, что наиболее часто на практике политический ярлык представляет собой тривиальный языковой знак, устанавливающий негативную, дискриминирующую связь между означающим и политическим явлением.

Ключевые слова и словосочетания: политические ярлыки, политическая мобилизация, пропаганда, социальные медиа, социальные сети, ВКонтакте, Telegram.

$\coprod$ ифровизаџия общества, рост популярности сощиальных медиа способствуют изменению методов политической борьбы и появлению новых механизмов 
мобилизаџии масс. В мировой науке активно исследуются и механизмы по формированию протестных движений через цифровую мобилизацию, и мировоззренческие установки индивидов. В частности, анализируется восприятие обшеством переплетения религиозных, государственных и политических явлений. Такой научный интерес обусловлен увеличением числа верующих, ростом авторитета религии, а также изменением тактик, стратегий и основных акторов политического проџесса.

Политические Авижения, политические партии, истеблишмент, политические мидеры все чаще используют религиозные и наџиональные ярлыки в выступлениях, призывах и политических акциях. В условиях нарастания процессов постсекуляризации возрастает актуальность информаџионных механизмов, при которых конфессиональный фактор через религиозные и наџиональные ярлыки может использоваться в качестве инструмента цифровой мобилизации, влияющего на национальную безопасность. Аанные факторы способны также спровоцировать общественно-политические риски.

ОАним из ярких примеров цифровой мобилизации, основанной на помитических и религиозных ярлыках, являются протестные комлективные Аействия в г. Екатеринбурге в 2019 г. и массовые шествия в Российской Федерации в начале 2021 г., связанные с арестом политического блогера А. Навального.

Эти политические события имеют ряд общих особенностей.

Во-первых, полное отсутствие соџиально-экономической повестки, социальных требований. Отметим, что у протестующих имемась сугубо помитическая повестка. Народные массы не выступали за повышение уровня жизни. Протесты в г. Екатеринбурге в 2019 г. воспринимаются в среАствах массовой информаџии как первая победа оппозиции над «системой». Массовые акщии протеста проходили в сквере на Октябрьской площади, где предполагалось строительство храма Святой Екатерины. Основной виА массовых действий выражался в виде флешмобов («перекличек»). Фактически причиной протеста явияось возведение забора в сквере.

Без соџиальной повестки прошли 23 и 31 января 2021 г. и протестные шествия в городах России, причиной которых послужил арест А. Навального. Формат комлективных действий был выбран по аналогии с хабаровскими протестами - шествие с требованиями освободить политического блогера.

Во-вторых, у комлективных действий - общий организатор. Организатором общественного Авижения «Скверубыты стал штаб А. Навального в г. Екатеринбурге [1]. Авижение политизировало конфцикт, проводило мобилизаџию масс через соџиальные сети, осуществмяло распространение информации в СМИ.

После задержания А. Навального 17 января 2021 г. начальник его федерального штаба $\Lambda$. Волков анонсировал проведение 23 января 2021 г. всероссийской акции в поддержку политика [2]. Штабы данной поли- 
тической симы выступили информационными источниками в соџиальных сетях и организаторами протестных шествий в городах России.

В-третьих, Аля политической мобилизации использовались социальные медиа и мощные информационные потоки информации, направленные на дискредитаџию действующей власти посреАством создания отриџательного образа храма, Президента РФ, федерального и регионального правительств. В ряде информационных сообщений использовался прием навешивания ярлыков - простой, мегко запоминаемой информаџии, негативно воспринимаемой в обществе.

Ранее политические ярлыки применялись непосредственно к политическим персонам, что является предметом изучения мингвополитической персонологии. Сегодня наблюдается навешивание ярлыков на политические процессы и явления. Возникает исследовательский интерес к механизмам и политическому значению данных технологий в соџиальных медиа, способных собирать массы на комективные действия с протестной повесткой при полном отсутствии соџиальной проблематики. Цель исследования заключается в теоретизации такого политического феномена, как политический ярмык в социальных медиа, и анализе практического применения данной технологии цифровой мобилизаџии масс. Философской основой опредемения понятия "ярлык» и его функционирования в политической сфере явАяются слеАУющие методологические ПоАХодЫ: прагматизм (Ч. Пирс), могический позитивизм (А. Витгенштейн) и структурализм (Ф. Ае Соссюр и Р. Якобсон).

Американский философ и основатель прагматизма и семиотики Ч. Пирс выделял три вида знаков: во-первых, подобия (likenesses), или иконы (icons), которые выполняют функцию передачи идей и репрезентируют вещи, просто имитируя их; во-вторых, указатели (indications), или индексы (indices), имеющие признак конкретной вещи, так как физически связаны с ней; в-третьих, симвомы, или общие знаки, которые ассоциируются с их значениями (meanings) благодаря привычке [3]. Именно символы и ассоциации формируются организаторами комлективных действий дмя попумяризации протестной повестки. Основой в данном контексте выступает созданная связь - привычка между знаком (ярлыком) и объектом.

Австрийский философ $\Lambda$. Витгенштейн в работе « трактат» раскрыц семь афоризмов, сопровождаемых разветвленной системой поясняющих предложений. Фактически фияософ предложиц теорию, решаюшую основные философские проблемы через призму отношения языка и мира. Язык отражает мир, потому что его могическая структура идентична онтологической структуре мира [4]. Мир преАставмяет весь набор существуюших фактов - и простых, и сложных. В языке простые факты описываются простыми предложениями, явцяющимися простейшими языковыми единиџами. Сложным фактам соответствуют сложные предложения. 
В системе ярлыков, по нашему мнению, сложные политические факты не описываются сложными предложениями, ибо им дается простое, даже тривиальное объяснение. Фактически упрощается могика объяснения факта за счет простого языкового знака.

Структуре знака посвящены работы швейцарского кингвиста, основателя семиологии Ф. де Соссюра. По мнению исследователя, языковой знак состоит из означающего (акустического образа) и означаемого (понятия). В языковом знаке как ярлыке следует выделить два основных свойства. Первое обусловлено тем, что, ярлык формирует произвольные связи межАу означающим и означаемым при усмовии отсутствия межАу ними внутренней, естественной связи. Второе свойство ярлыка состоит в том, что означающее обцадает протяженностью в одном измерении (во времени) [5].

Подробно ярлыки в качестве политических символов исследовали Р. Кобб и Ч. Эмдер. Они заложкили методологию анализа политических символов, разработали их классификацию, выявили специфику. В США поА ярлыками чаще используют понятие принадмежности к той или иной идеологии или политической партии. Используются такие ярлыки, как миберальный, умеренный, прогрессивный, консервативный, мибертарианский, чтобы позиџионировать себя по отношению Аруг к Аругу. Распространенными явмяются ярлыки «ослы» Аця преАставителей демократической партии и «слоны» Аля республиканцев [6, с. 131].

В российской политической системе подобные ярмыки встречаются реАко. В соответствии с внутрироссийской политической спеџификой существуют позитивные политические символы (например, «Крым наш», «вежливые мюди») и ярлыки, имеющие мишь негативное значение. В работах И.В. Николаева [7, с. 31] и В.Э. Багдасаряна [8, с. 101] проводится подробный анализ политических символов России, а также методов их формирования. Понятие «ярлык» раскрывается как слово или характеристика, употребляемое с целью дискредитировать движение, партию в глазах избирателей, гражАан. Применительно к политической борьбе слова-ярмыки навязчиво используются в СМИ, социальных медиа, на телевидении. Ярчайшими примерами ярлыков, которые призваны вызывать у насекения сугубо отрицательные эмоџии, явмяются слова «фашист», «экстремист», «нацист», «расист», «ксенофоб», «коррупция», «взятка» и т.п. [9].

Политический ярлык, на наш взгляА, преАставляет собой тривиальный языковой знак, устанавмивающий негативную дискриминирующую связь межАу означающим и политическим явлением. Ярлык формирует привычку у граждан воспринимать определенное политическое явление через негативный образ, изначально принадлежащий ярлыку. Соответственно, «религиозные» ярлыки затрагивают те области понятий, которые связаны с религиозным культом, конфессиями, религиозными традициями, ценностями, христианскими заповедями, библейскими сюжетами, скужи- 
телями религиозного культа, религиозными организациями, культовыми сооружениями.

Процесс навешивания политических ярлыков заключается в упрощении объяснения сложного политического явления и дает возможкность цегче воспринять сложную политическую реальность. Ярлык может нести Аискриминационный характер Аля какого- иибо социального или политически значимого явления через его именование с помощью языковых знаков, стереотипов, мифов, ассоциаций.

Научный интерес вызывает механизм вцияния ярлыков на мобилизацию протестных масс. В рамках Аанного исследования проведен анализ общероссийских социальных медиа, а также социальных медиа Свердиовской области (группы ВКонтакте, Telegram, Instagram), в ходе которого выявлена негативная эмоциональная тональность попуцярных постов в социальных сетях. В периоды с апреля по август 2019 г. и с лекабря 2020 г. по февраль 2021 г. исследовались наиболее популярные группы в ВКонтакте: ЁП (8 750864 подписчика), «Четкие приколь» (8 428682 подписчика), MDK (7 702094 подписчика), «Убойный юмор» (6 306943 подписчика), БОРШ (5 647302 подписчика), Орленок (2 414516 подписчиков), Институт благородных девиџ (3 286330 подписчиков), а также страницы Аанных групп в Telegram и Instagram.

Анализ информационных постов показывает слеАующий ацгоритм навешивания ярлыков:

1. Ознакомление населения с проблемой.

2. Навешивание ярлыка, формирование негативной ассоциации.

3. Объяснение проблемы через ярлык (весьма тривиальное).

4. Выдвижение требований;

5. Организация комлективных действий, трансформация ярлыка в симвоц протеста.

Перъъй этап - ознакомление населения с проблемой. В случае со строительством храма в сквере г. Екатеринбурга проблема была обозначена как захват общественной земли под строительство храма местной политической и экономической элитой. Организаторы комлективных действий назвали строитемями ФонА Святой Екатерины, который объеАиняет почти весь крупный бизнес города [10]. Фактически строительство храма бымо преподнесено в регионацьных оппозиционных СМИ как попытка современной индумьгенџии и замаливания грехов, при этом активно обсуждацись проблемы нехватки зеленой (рекреационной) зоны, Аетских пцощадок, места дия выгула собак, элементарных мест Аля прогулок.

Bmорой этап - навешивание ярлыков. В ходе проведения агитационной кампании противниками строительства использовалось несколько символов. Так, позицию «Не трогайте природу» выражкала девушка в русском сарафане с крупными цветами. В соџиальных медиа появились ярлыки: «СкверныйХрам», «Бизнес-храм», «Храм на Араме». 
Как следствие, популярные социальные медиа поддержали тему борьбы за сквер, которая транслировалась как борьба народа за природу против бизнес-элиты, истеблишмента, стремящихся к замаливанию своих грехов. Информационные посты на эту тему, наиболее распространенные в Интернете [11], приобрели особую эмоџиональную тональность Широкую популярность приобрело изображение г. Екатеринбурга, застроенного храмами с подписью "Аепота-то какая». Использовалось также изображение проекта храма Святой Екатерины, выделенного красным цветом (по аналогии с компьютерными играми) с подписью «ЗАесь нельзя строить, мицорА».

Третий этап - объяснение проблемы - можно наблюдать наблюдать в социальных сетях штаба А. Навального в г. Екатеринбурге. Аргументы против строительства храма следующие: это издевка над екатеринбуржцами, подарок олигархов, моббирование РПЦ, законность стройтреста поА большим вопросом, центру Екатеринбурга жкутко не хватает парков [12] . Вместе с объяснением проблемы было выдвинуто простое требование (четвертьй этап): «Храма быть не Аолжно».

Пятьй этап - организаџия комлективных действий - представмяет собой работу в соџиальных медиа и сбор сторонников - граждан, откцикнувшихся на яркие медийные ярлыки. Среди коммективных действий использовались фмешмобы-переклички, скаканья с мозунгом «Кто не скачет, тот за храм», снос забора.

Подобный механизм в комективных действиях применяяся 23 и 31 января 2021 г. в городах России. Проблемы обозначались как «Россия - полицейское государство» [13]. Штаб А. Навального предполагал задержкание блогера после его прибытия на территорию Российской Федераџии из ФРГ, что подтверждает скорый выпуск агитационного фильма «Аворец Путина. История самой большой взятки» [14], вызвавшего определенный резонанс в обществе. В фильме использовались такие ярлыки, как «царь, «аквадискотека» «ёршик за 150 тысяч рублей», «самая большая взятка» и т.п. Череда комлективных действий в городах России 23 и 31 января 2021 г. представмяла собой протестные шествия с мозунгами «Он нам не царь», «Позор», «Отпускай», «Пропускай».

Таким образом, представменные технологии, по нашему мнению, были направлены на формирование упрощенного восприятия сложных политических процессов. Ярлык позволяет переключить граждан от анализа к соглашению исходя из простых могических конструкций, клише, отрицательных образов.

Негативный политический ярлык представмяет собой простой, языковой знак, устанавливающий дискриминирующую связь межАу означающим и политическим явлением. Проџесс навешивания политических ярмыков заключается в дискредитаџии какого- ибо соџиально и политически значимого явления путем его именования с помощью языковых знаков, 
стереотипов, мифов, ассоџиаций. Современная тактика навешивания ярмыков заключается в ознакомлении населения с проблемой через призму ярлыка, формирование негативной ассоџиаџии. Объяснение проблемы дмя широких масс населения происходит также через ярлык, что достаточно тривиально, при этом выдвигаются простые и понятные обывателю требования, коммективные действия в качестве завершающей части трансформируют ярлыки в символ протестных действий.

\section{Библиографический список}

1. «Защитники сквера» наносят новый удар. URL: https://eburg.mk.ru/social/2019/05/22/ zashhitniki-skvera-nanosyat-novyy-udar.html.

2. Волков Л. Новые акции протеста. URL: https://meduza.io/news/2021/01/23/leonidvolkov-anonsiroval-novye-aktsii-protesta-cherez-nedelyu

3. Пирс Ч. Что такое знак? // Вестник Томского государственного университета. Философия. Социология. Политология. 2009. № 3 (7). С. 88-95.

4. Витгенштейн Л. Логико-философский трактат / пер. с нем. И.С. Добронравова, Д.Г. Лахути; общ. ред. и предисл. В.Ф. Асмуса. М., 1958 (2009).

5. Соссюр Ф. де Курс общей лингвистики / пер. с франц. А.М. Сухотина; под ред. и с примеч. Р.И. Шор. М., 2004.

6. Кобб Р., Элдер Ч. Использование символов в политике / пер. с англ. И.С. Поляковой // Политическая лингвистика. 2009. № 3 (29). С. 131-145.

7. Николаев И.В. Вербальные политические символы в коммуникации общества и власти: опыт типологизации // Социодинамика. 2021. № 1. С. 32-43.

8. Багдасарян В.Э. Политическая символика. М., 2018.

9. Политический словарь. «Политические ярлыки». URL: https:/gufo.me/dict/politics dict $\% \mathrm{D} 0 \% \mathrm{AF} \% \mathrm{D} 1 \% 80 \% \mathrm{D} 0 \% \mathrm{BB} \% \mathrm{D} 1 \% 8 \mathrm{~B} \% \mathrm{D} 0 \% \mathrm{BA}$

10. На чьи деньги строят храм в г. Екатеринбурге. URL: https:/www.kp.ru/daily/26977/4036139/

11. Пользователи шутят над противостоянием сторонников и противников строительства храма на месте сквера в Екатеринбурге. URL: https://versia.ru/polzovateli-shutyat-nadprotivostoyaniem-storonnikov-i-protivnikov-stroitelstva-xrama-na-meste-skvera-v-ekaterinburge

12. «Храм на Драме» - почему его быть не должно. URL: https://shtab.navalny.com/hq/ ekaterinburg/933/

13. О деле Навального и полицейском государстве. URL: https://echo.msk.ru/blog/ schlosberg_lev/2776542-echo/

14. Официальный Youtube канал А. Навального. URL: https://www.youtube.com/ watch? $\mathrm{v}=$ ipAnwilMncI 